\title{
THE ISSUES OF REAL ESTATE VALUATION IN THE PROCESS OF PRIVATIZATION
}

\author{
Levan KALANDADZE
}

\author{
Tbilisi State University, Georgia \\ Corresponding author e-mail: levanikala130187@gmail.com
}

\begin{abstract}
The process of privatization in our country was characterized and unfortunately is still characterized by very important difficulties. The purpose of the research is to analyze the issues of real estate valuation in the process of privatization. In Georgia, the privatization process began after dissolution of the Soviet system. It should be noted that the process of privatization is of particular importance in terms of activation of investment activities in the country. In this regard, privatization can be considered one of the essential and most important incentives for attracting investments by the state. Currently, thousands of enterprises have already been privatized, but there are still quite many stateowned production facilities and property. Determination of the market value of the items of state-owned property is especially important when selling them at auctions or on competitive basis. In addition, one of the causes for incompetent privatization of the state-owned property at the early stage is disregard of the institute of appraisers of movable and immovable property, who did not participate in determining the market value of the property and in the privatization process. The information assessment, analysis, comparison and generalization, as well as systematic, quantitative, qualitative and logical generalization methods are used in the article.
\end{abstract}

Keywords: Evaluation, investment, market value, privatization, real estate.

\section{INTRODUCTION}

The process of privatization in Georgia was characterized and unfortunately is still characterized by very important difficulties.

The purpose of the research is to analyze the issues of real estate valuation in the process of privatization. The tasks of the research are to review legislative norms; to substantiate the amendments to be made on the basis of legislative norms; to study the real estate market; to determine the need for the involvement of the appraiser in the privatization process. Based on the research purposes, the objectives of the research are: to analyze the norms of legislative frameworks; to study the real estate market; to evaluate the role, activities and functions of subjects participating in the real estate market; to study the causes of problems arising in the in real estate evaluation process and to find their solutions; to study the challenges and risks associated with undervaluation of real estate in the process of investing in real estate and in privatization process.

Methodological basis for research. Based on the practical significance of the problem of the research, the information assessment, analysis, comparison and 
generalization, as well as systematic, quantitative, qualitative and logical generalization methods are used in the article.

The initial process of privatization in our country was entirely based on the privatization or so called "Voucherization" process implemented in the former Soviet Union and first of all in Russia. Undoubtedly, this process turned out to be unsuccessful as the value of the major funds was artificially reduced by the directorate of enterprises, which resulted in the reduction of the value of the shares of the enterprises to be purchased using vouchers almost to zero. Therefore, the voucherization itself did not make sense as devalued shares were massively purchased by the directorate of enterprises and they tried to take possession of the enterprises in this way. As a result of voucher privatization, the property turned out to be fragmented between small investors who did not own the capital for development of enterprises and who, most importantly, lacked management experience (Barbakadze, 2016). Obviously, such process negatively impacted investment activities in different sectors of the economy.

The next stage of privatization began in Georgia in 1998, when the focus was directed to the privatization of large energy facilities. In this process special attention was paid to attracting the interest of foreign investors. It should be noted that the mistakes made in the first stage of statehood, which resulted in the hardest financial crisis of these large facilities, led to significant reduction in their auction price. As a result, this stage of privatization did not prove to be effective.

After the so-called "Rose Revolution" of 2003, the third stage of privatization was carried out in Georgia, which was focused on attracting foreign investments and creating a more favorable environment for businesses. It is noteworthy that in the initial stage of privatization, there was no mechanism developed in Georgia for determining the privatization strategy or the terms for foreign investors to participate in this process. Investor, interests might have been entirely inconsistent with the directions of the development of Georgia's economy according to the principles of market economy.

\section{GENERAL REGULATIONS}

Currently, in Georgia there are the following forms of privatization of stateowned agricultural land: auction; direct sale; competitive direct sale; and gratuitous transfer based on the special decision of the President of Georgia. The forms of privatization of other types of state-owned real estate are auction, direct sale, and competitive direct sale.

It should be necessarily noted that when selling state-owned property at auctions or on competitive basis, it is especially important to determine its real market value. In addition, according to some researchers, one of the causes for incompetent privatization of the state-owned property at the early stage is disregard of the institute of appraisers of movable and immovable property, who did not participate in determining the market value of the property and in the privatization process. "Due to the legislative vacuum, the property is valued by the auditors who lack relevant qualification and do not use international standards that results in subjective approach to the valuation process and lamentable condition on the real estate market of Georgia in general" (For.ge, n.d.). 
The following factors can be named as the causes of the deficiencies in the privatization of the state property in Georgia: the importance and perspectives of the facilities were not fully taken into consideration while the property to be privatized was valued; in addition, its value was artificially reduced. Discrepancies which occurred while selling such important properties as JSC "Madneuli", JSC “Quartzite', "Tbilgazi", Georgian ocean fleet and others are examples of the above-said.

It should be noted that land in our country used to be the object of nationalization and did not participate in economic circulation for a long time. Therefore, during the initial years of independence, it was included with normative price in the system of economic relations. It was assumed that based on the normative price a methodological base would be set up for land privatization and land lease relationships and thus the land market would be set in motion. But as practice showed, market value of land plots in economically developed regions of the country significantly differs from the prices calculated by the normative acts. In addition, as we know, the value of real estate is determined by a number of factors. Some of the important factors to be mentioned are supply and demand for real property, utility of the facility, its location, revenue received from operating the facility, etc.

It is noteworthy that on May 22, 2012, an important step was taken towards regulating valuation of real estate when the meeting was held in relation to launching the project of mass valuation of real estate in Georgia. The meeting was initiated by the LEPL National Agency of Public Registry of the Ministry of Justice of Georgia. The meeting was attended by the representatives of Public Registry, Revenue Service, Ministry of Economy and Sustainable Development, Chamber of Control, National Bank, National Forensics Bureau, National Bureau of Enforcement, Tbilisi City Hall, as well as representatives of commercial banks, audit companies, construction development companies and private assessors. As it was announced, the goal of the project was the development of a unified model for mass valuation of real estate based on successful international experience. In the first stage the model would be used by administrative bodies (Gongladze, 2012).

In recent years, real estate was simultaneously valued both by auditors and appraisers in Georgia. In addition, respective valuation services were established with the same purpose in a number of administrative agencies (such as National Bureau of Enforcement, Revenue Service, National Forensics Bureau, Tbilisi City Hall and others). As it was declared at the above-mentioned meeting, the project of mass valuation system would ensure the introduction of a unified, standardized approach in the valuation of real estate in Georgia. The Swedish experience in the field of mass valuation, the plan for launching a similar system in Georgia, methodological and training groups for mass valuation, formation of coordination council and other important issues were also discussed at the meeting.

The meeting was important for both private and public sector representatives as the project of mass valuation system promotes valuation of real estate using unified and standardized methodology. It is noteworthy that the project of mass valuation system in our country was supported by the Swedish International Development Agency (SIDA).

Resulting from the recognition of importance of property valuation, the Law of Georgia on Accounting, Reporting and Audit was issued by the president of 
Georgia in July, 2016. Paragraph 8 of Article 28 of Chapter VIII of the abovementioned Law says, "The Government of Georgia shall elaborate a legislative act in respect to valuation activities before December 31, 2017. Before its enactment: ... b) accredited valuation certification authorities, which are members of the International Valuation Standards Council (IVSC) shall provide Georgian version of international valuation standards; c) the right of delivering valuation services shall be granted only to the company, which employs appraisers certified by the accredited valuation certification body. The right of valuation and signing the valuation statement/conclusion shall be granted to the appraisers certified by the accredited valuation certification body" (the Law of Georgia on Accounting, Reporting and Audit, 2017). Regulation of the valuation issues at the legislative level will increase interest of world financial institutions and potential investors in Georgia, which, in turn, will enable development of complex development programs for definite economic projects.

Privatization of the state property is carried out for the development of free business environment in our country. The number of the auctions announced by LEPL National Agency of State Property of the Ministry of Economy and Sustainable Development of Georgia are shown in Figure 1 and Figure 2.

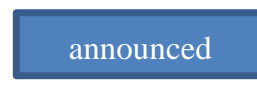

1582

auctions

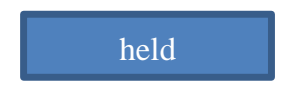

928

auctions

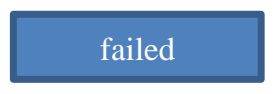

580

auctions canceled

19

auctions

Fig. 1. Auctions announced in 2016 (National Agency of State Property, n. d.).

Announced auctions

Held auctions

Failed auctions

Canceled auctions

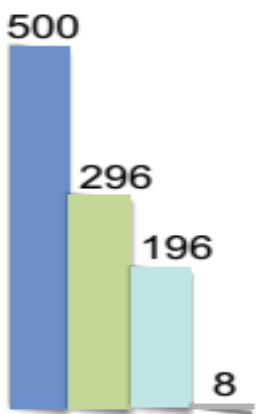

I quarter of 2016

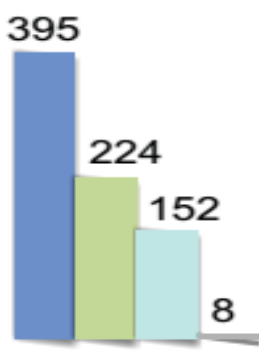

II quarter of 2016

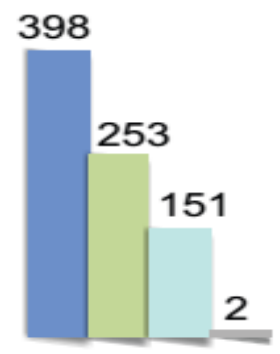

III quarter of 2016

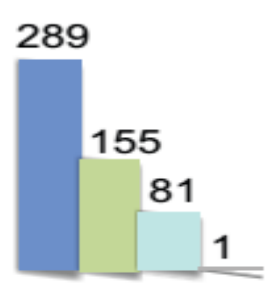

IV quarter of 2016

Fig. 2. Table on the auctions announced in 2016 (National Agency of State Property, n. d.). 
The cost of privatized property and revenues to the state budget of Georgia in recent years as a result of activities implemented by the LEPL National Agency of State Property comprise:

- actual revenue to the state budget (GEL, National currency Lari);

- The cost of privatized property (GEL, National currency Lari).

The cost of privatized property and revenues to the state budget of Georgia were the higest in year 2015. The cost of privatized property and revenues to the state budget of Georgia are shown in Figure 3.

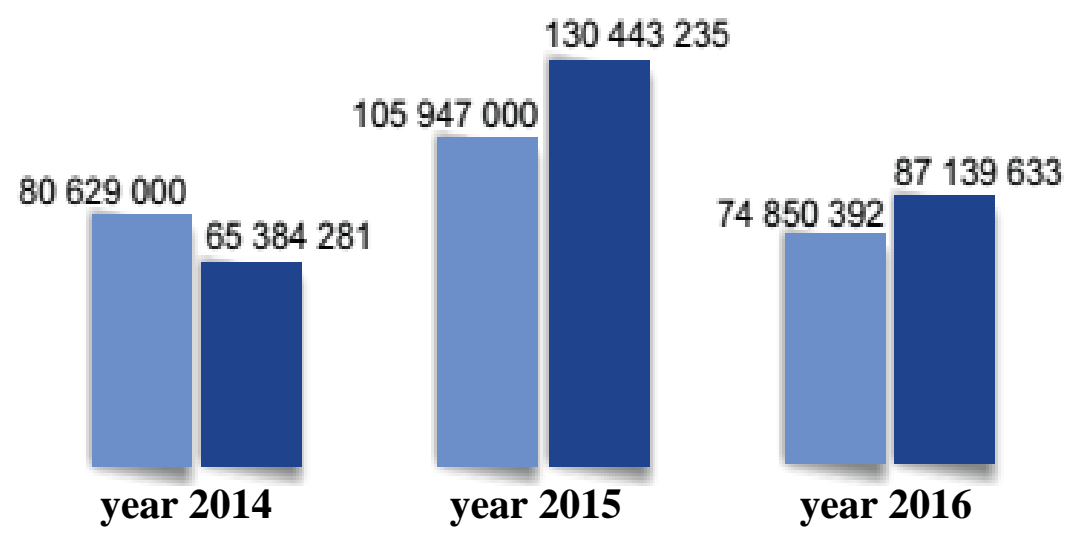

Fig. 3. Table on the auctions announced in 2014, in 2015, in 2016 (National Agency of State Property, n. d.).

Today, the current costs (approximate) of different types of real estate in the districts of Tbilisi, the capital of Georgia, are shown in Figure 4 to Figure 7.

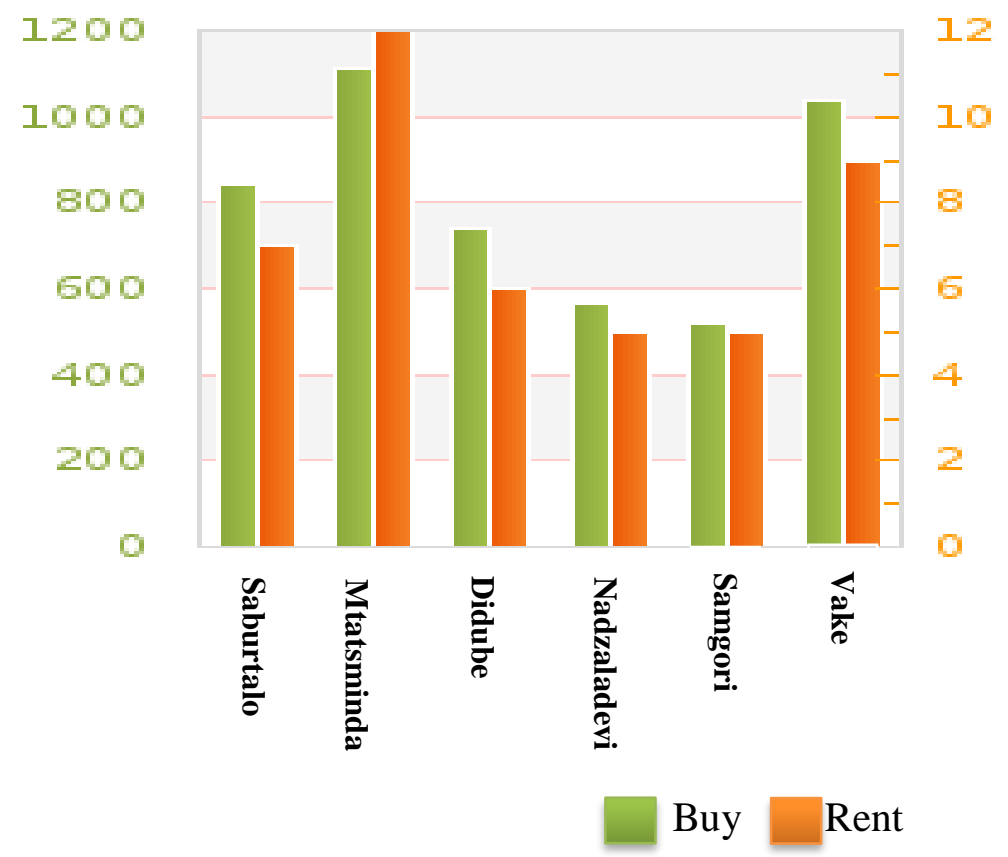

Fig. 4. Residential real estate (cost per $\mathrm{m}^{2}$ in US dollars (\$) (Makler.ge, n.d.). 


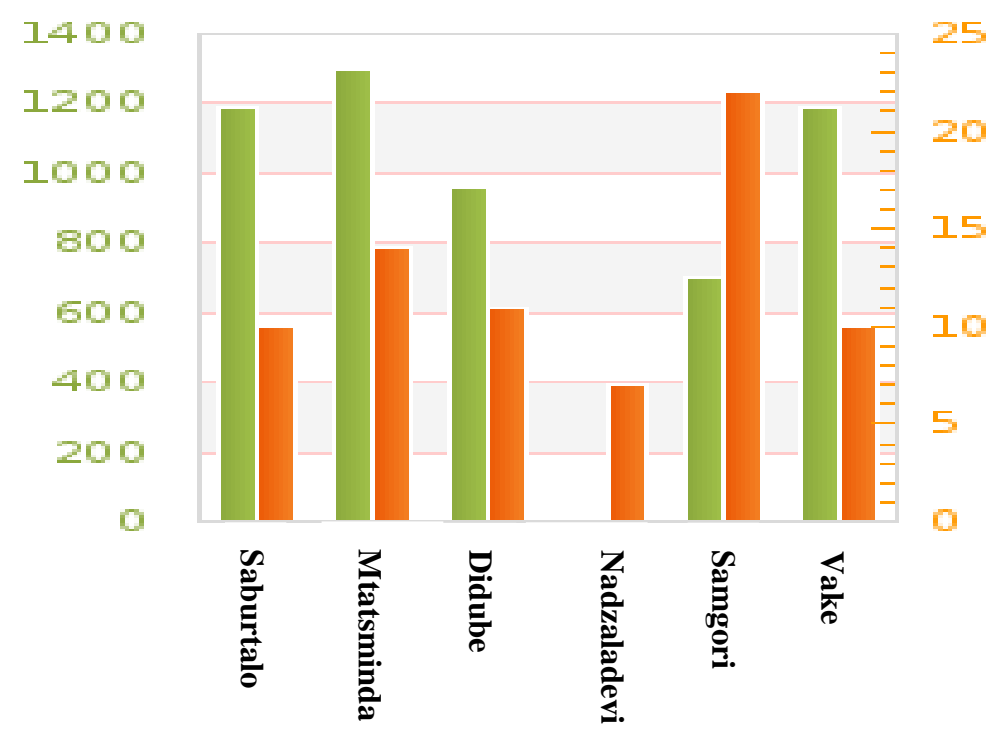

Buy Rent

Fig. 5. Office real estate (cost per $\mathrm{m}^{2}$ in US dollars (\$) (Makler.ge, n.d.).

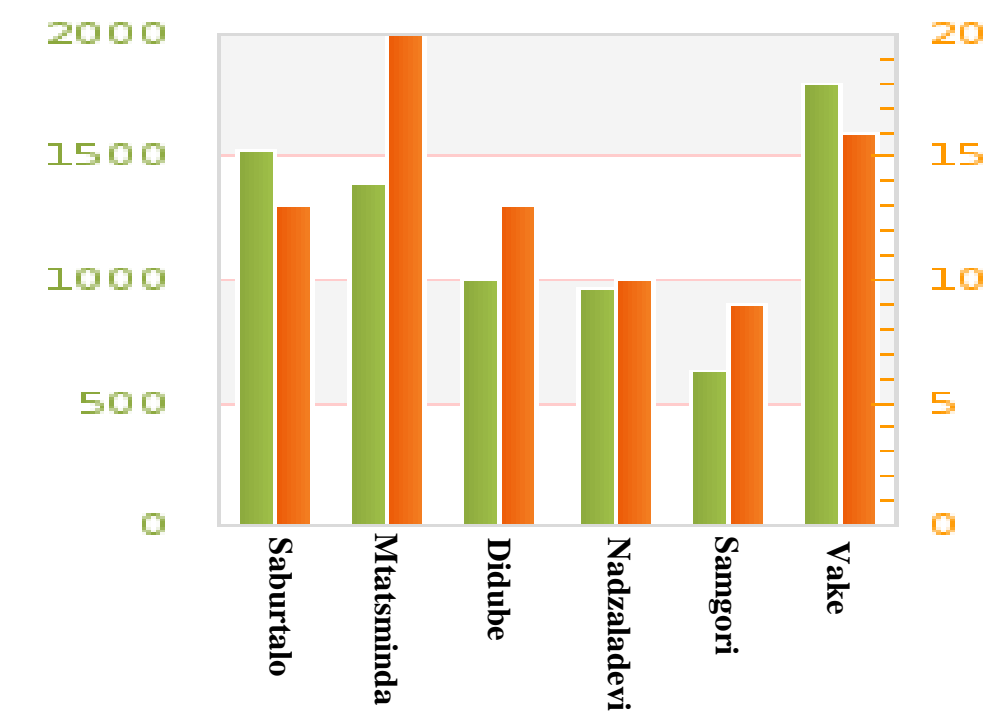

Buy Rent

Fig. 6. Commercial real estate (cost per $\mathrm{m}^{2}$ in US dollars (\$) (Makler.ge, n.d.). 


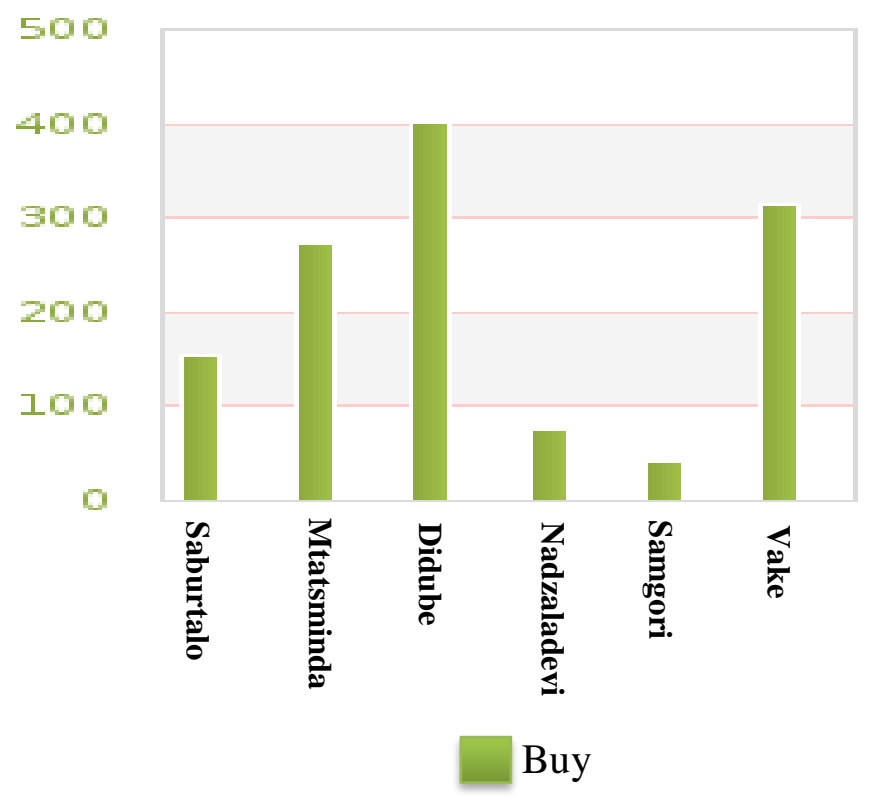

Fig. 7. Vacant land plots (cost per $\mathrm{m}^{2}$ in US dollars (\$) (Makler.ge, n.d.).

The situation on the real estate market within different regions differs. Current economic system shows also different market development tendencies in the sales and rent markets.

\section{CONCLUSION}

The following reasons have been identified as causing deficiencies in the privatization of state property in Georgia in various stages of privatization: the importance and perspectives of the facilities for privatization were not fully taken into consideration in the process of valuation. In addition, their value was artificially reduced. Stronger involvement of professional appraisers is very important for protecting the interests of local and foreign investors in the process of privatization of state property in Georgia and enhancing the effectiveness of investment in the country. This will help avoid the problems, which were characteristic for our country in the nearest past.

\section{REFERENCES}

The Law of Georgia on Accounting, Reporting and Audit. (2017). 08.06.2016. Retrieved from https://www.saras.gov.ge/Content/files/LAW_ON_ACCOUNTING_REPORTING_AND_AUDIT ING_V2_2017.07.05.pdf

Gongladze, S. (2012, May 23). How Real Estate Will be Evaluated. Newspaper Akhali Taoba.

Barbakadze, K. (2016). About Financial Assurance of Small and Medium Enterprises. Proceedings of the 24th International Academic Conference, June 28 to July 1, Barcelona, ISBN 978-80-87927-25-0. https://doi.org/10.20472/iac.2016.024.010

National Agency of State Property. (n. d.). Privatization. Retrieved from www.nasp.gov.ge

Makler.ge. (n. d.). Statistics. Retrieved from www.makler.ge

For.ge. (n. d.) Colossal elite corruption. Retrieved from

http://www.for.ge/view.php?for_id=14333\&cat=12 


\section{AUTHORS' SHORT BIOGRAPHY}

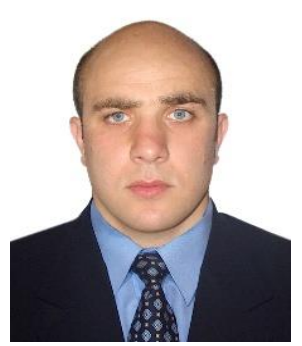

Levan Kalandadze is a $\mathrm{PhD}$ student of $\mathrm{PhD}$ Program in Business Administration of the Faculty of Economics and Business, TSU (last course); 2009-2011 - Master Degree in Business Administration (Finance and Banking) at the Faculty of Economics and Business, TSU; 2004-2008 Bachelor Degree in Business Administration (Finance and Banking) at the Faculty of Economics and Business, TSU (with honours); Work experience: from 2010 - valuer at the National Bureau of Enforcement's assessment service (Ministry of Justice of Georgia); 2015-2016 - lecturer at the Faculty of Economics and Business, Tbilisi State University; from 2011 - Real Estate Certified Evaluator; 2010 - Tax-Customs Department, Revenue Service, Ministry of Finance; 2010 expert in Commodity, Financial and Engineering Expertise Department, LEPL Levan Samkharauli National Forensics Bureau; Published scientific articles: Legal Issues Related to Investing in Real Estate - Business and Law, no. 2 April-June, 2017; Analysis of Land Plot Assessment Methods New Economist, no. 2, 2017; Analysis of the Best and Effective Use of Real Estate - Georgian Economics, 20.07.2017. Virtual/Cryptographic Currency Bitcoin and Its Introduction Perspectives in Georgia - Iinternational scientific conference, Challenges of Globalization in Economics and Business.

E-mail: levanikala130187@gmail.com 